\title{
CYSTATHIONINURIA IN HEPATOBLASTOMA
}

\author{
P. A. VOUTTE, Jr. AND S. K. WADMAN \\ Emma Kinderziekenhuis, Amsterdam and the Laboratory of the Wilhelmina Kinderziekenhuis, \\ Utrecht (The Netherlands) \\ (Received June 27, 1968)
}

SUMMARY

A second case of cystathioninuria in hepatoblastoma is described. In addition to the urinary amino acids also the amino acids of serum and tumour tissue could be analysed.

The origin of the urinary cystathionine is discussed. The data suggest that the tumour itself rather than a diseased liver is the source of this amino acid.

The excretion of cystathionine by a patient with hepatoblastoma has been described by Gjessing and Mauritzen ${ }^{1}$. We can now provide more detailed and quantitative data on a similar patient since we have had the opportunity to study the amino acids of urine, serum and tumour tissue.

Cystathioninuria is not characteristic for hepatoblastoma. Patients with neurogenic tumours occasionally excrete this amino acid; it has been found also in adults with hepatoma. On the other hand, cystathioninuria is not necessarily connected with tumours. Its occurrence in patients with tumours and in other conditions has been reviewed by Shaw et al. ${ }^{2}$. Presumably, a deficiency of cystathionase or a defective cystathionase is the cause in primary or congenital cystathioninuria. A secondary form results from vitamin $B_{6}$ deficiency. Patients with severe liver disease may excrete varying amounts of this amino acid. The question of the origin of the urinary cystathionine in hepatoblastoma is important. Is this amino acid produced by the tumour itself or is its appearance a sign of a disturbed amino acid metabolism in a damaged liver? If the first is true, can we then trace the mechanism responsible for its formation? Our data may contribute to an answer to these questions.

\section{The patient}

J.L.L. (m), born in November '66, was admitted in August ' 67 with a tumour in the right hypochondrium. He had no other clinical complaints, normal liver tests (GOT, GPT, alk. phosphatase, thymol turbidity), normal renal function tests and a normal sedimentation rate of the erythrocytes. Neuroblastoma was improbable since the excretion of vanilglycolic acid and vanilacetic acid were not increascd. The intravenous pyelogram was normal, excluding a nephroblastoma. At operation a large tumour in the right lobe of the liver was revealed and a hemihepatectomy was per- 
formed. The tumour was parti-coloured: gray-white to yellow with spots of necrosis. Following the operation the patient died.

\section{Microscopic examination of the tumour (J. F. M. Delemarre, Netherlands Cancer Institute)}

The tumour had a trabecular structure. The trabecula were surrounded by sinusoids, as is always seen in normal liver parenchyma. The cells were polygonal and showed some pleiomorphism. The cytoplasm contained eosinophilic granulae. The nuclei were round and had a course chromatin pattern and nucleoli. There were changes to a type of large puffed cells, but also groups of spindle-shaped cells were seen and, in particular, cylinder-shaped cells surrounding certain cavities in the tumour. Large blood-filled cavities were surrounded by polygonal tumour cells. Bils plugs were seen between the tumnur cells. Signs of haemopoiesis were not present. Between the tumour and the liver there was a zone of hyaline connective tissue, infiltrated by the tumour.

Diagnosis: Epithelial hepatoblastoma, mainly of an embryonal cell type.

\section{MATERIALS AND METHODS}

Fasting serum and tumour tissue were obtained on the day of operation. Collection of 24 -h urine was started on the preceding day. Two-dimensional paper chromatography of urinary amino acids was perfomed as described before ${ }^{3}$. Oxidation of sulphur-containing amino acids was performed on the chromatogram with $0.005 \mathrm{ml}$ of $\mathrm{H}_{2} \mathrm{O}_{2}(30 \%)$ containing $2 \mathrm{mg}$ ammonium molybdate per $5 \mathrm{ml}$.

Homocitrulline was detected by spraying with p-dimethylaminobenzaldehyde: $2 \mathrm{~g}$ in $20 \mathrm{ml} 6 \mathrm{~N} \mathrm{HCl}+80 \mathrm{ml}$ ethanol. In addition, its presence was proved by chromatography in isopropanol-5\% ammonia (4:T) followed by $n$-butanol-acetic acidwater $(4: I: I)$.

The latter system was also used for the detection of xanthurenic acid. This substance was extracted from the urine with deactivated charcoal according to Dalgliesh ${ }^{4}$. A volume of the extract corresponding to $2 \mathrm{ml}$ of urine was applied on the 2-dimensional chromatogram. Xanthurenic acid was detected with diazotized sulphanilic acid. The method used for vanilmandelic and vanilacetic acids has been described by one of us $^{5}$. Essentially, the paper-chromatographic method of Armstrong et al. ${ }^{6}$ was followed. Spots were evaluated by visual comparison with known amounts run through the same procedure. Quantitative column chromatography of urinary amino acids was performed with a Technicon amino acid analyser $(22-\mathrm{h}$ method). Serum was ultrafiltered and for separation the $12^{1 / 2}$-h method was used?. The tumour was frozen immediately after removal; $23 \mathrm{~g}$ of frozen tissue was homogenized with $27 \mathrm{~g}$ of water. The homogenate was ultrafiltered. Amino acids in the ultrafiltrate were estimated as in urine. Concentration in tissue $=50 / 23 \times$ concentration in ultrafiltrate.

RESULTS

Paper chromatography of the urinary amino acids brought to light an enhanced excretion of cystathionine. A typical chromatogram is shown in Fig. $I$. In Table I, the 


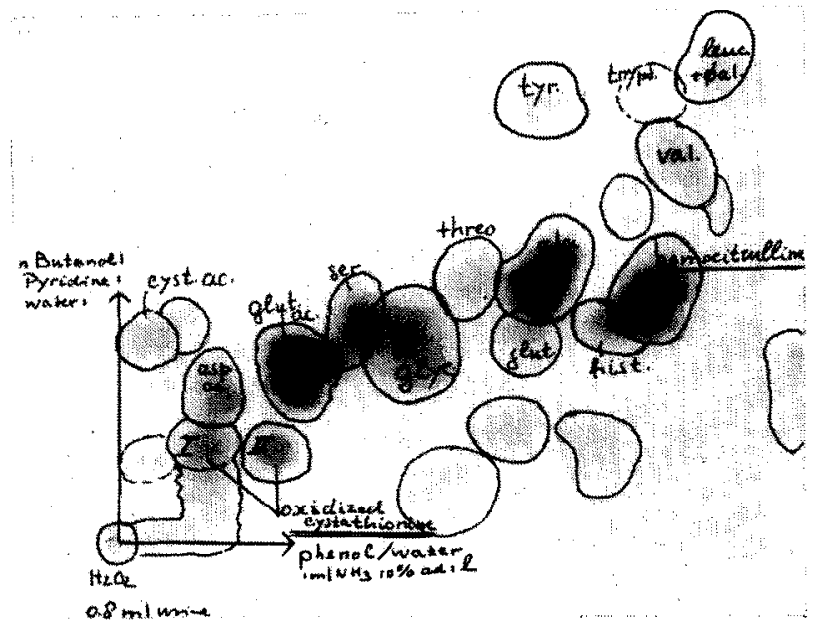

Fig. I. Cystathioninuria in hepatoblastoma: a two-dimensional paper chromatogram of urinary amino acids.

results of column chromatography are listed. We found $1238 \mathrm{mg}$ of cystathionine per gram of creatinine. That is 6 times the value mentioned by Gjessing and Mauritzen ${ }^{1}$ for their patient. Our patient excreted only $18.4 \mathrm{mg}$ of creatinine per $24 \mathrm{~h}$, whilst 5 controls produced 74.3 on an average (range $56-102.5$ ). Thus the high value for cystathionine per gram of creatinine may be in part a reffection of a low creatinine production.

The 24 -h excretion of cystathionine was $22.9 \mathrm{mg}$, at a daily intake of $0.4 \mathrm{I} \mathrm{g}$ of its precursor methionine.

\section{TABLE I}

URINARY AMINO ACIDS ANALYSED BY COLUMN CRROMATOGRAPHY AND CALCULATED AS Mg per gram OF CREATININE

24-hour urine, $3 \pm 8 \mathrm{ml}$; creatinine $18.4 \mathrm{mg}$ per $318 \mathrm{ml}$.

\begin{tabular}{|c|c|c|c|}
\hline Amino acids & $\begin{array}{l}\text { Creatinine } \\
\text { mglg }\end{array}$ & Amino acids & $\begin{array}{l}\text { Creatinine } \\
\text { (mglg) }\end{array}$ \\
\hline Cysteic acid $+(?)$ & $(37)$ & Cystine & 19 \\
\hline Taurine + (?) & $(106)$ & Methionine & ro \\
\hline Aspartic acid + (?) & $(200)$ & Cystathionine & 1238 \\
\hline Threonine & 41 & Isoleucine & II \\
\hline Serine & I 68 & Leucine + (?) & $\mathrm{n} \mathbf{r}$ \\
\hline Glutamic acid & 107 & Tyrosine & 89 \\
\hline Citrulline & I6 & Fenylalanine & $4^{8}$ \\
\hline Glycine & 380 & Homocystine + (?) & 3 I $\max$. \\
\hline Alanine & I 64 & Ornithine $+(?)$ & n r \\
\hline$\alpha$-Aminobutyric acid & 6 & Lysine + ? & $(57)$ \\
\hline \multirow[t]{2}{*}{ Valine homocitrulline } & $(297)$ & Histidine + (?) & $(244)$ \\
\hline & & Arginine & 9 \\
\hline
\end{tabular}

Data between brackets are calculated roughly from asymmetric peaks; $\mathrm{n} r=$ not resolved and therefore not calculated; $\max .=$ maximum possible concentration.

Although it is unsafe to interpret a single analysis biologically, we presume that the level of the excretion in our patient is not exceptional, compared with other types 
of cystathioninuria ${ }^{2}$. In this connection, our results of amino acid estimation in the urine of a patient with hepato-renal syndrome can be mentioned. This patient (P.P.) excreted up to $734 \mathrm{mg}$ of cystathionine per gram creatinine. Another patient (I-ycarold P.v.B.) with a neurogenic tumour excreted $33.8 \mathrm{mg}$ per $24 \mathrm{ll}$ and per $48.3 \mathrm{mg}$ of creatinine. Just before death, cystathionine excretion was highest, as was the excretion of vanilglycolic acid, vanilglycol and vanilacetic acid. The excretion of cystathionine and metabolites of catecholamines run roughly parallel.

TABLE: II

AMINO ACIDS IN SERUM AND TUMOUR TISSIE, ANALYSED BY COILMN CHROMATOGRAPHY

\begin{tabular}{|c|c|c|}
\hline & $\begin{array}{l}\text { Fasting somm } \\
\text { molsoo wh } \\
3 \text { s }\end{array}$ & $\begin{array}{l}\text { Thwous } \\
\text { mg/IOS } g \\
30-8\end{array}$ \\
\hline Cysteic acid & & I. . I \\
\hline 'laurine & $2.8 \mathrm{I}$ & 8.7 \\
\hline Methionine $\$(0$ & 0.09 & I. 6 \\
\hline Aspartic acid & 0.75 & $2 \mathrm{I} \cdot 7$ \\
\hline Threonine & 1.25 & 31,2 \\
\hline Serine & 2.22 & 52.9 \\
\hline Glutamic acid & 0.96 & 107 \\
\hline Proline & 2.38 & 27.6 \\
\hline Citrulline & 0.27 & I. .2 \\
\hline Glycine & r. 68 & 3.5 .8 \\
\hline Mlanine & 1.91 & $5^{\circ} \cdot 1$ \\
\hline$\alpha$-Aminobutyric acid & 0.10 & 1.8 \\
\hline Valine & 2.33 & 29.9 \\
\hline Cystine & & $4+4$ \\
\hline Methionine & 0.27 & 10.0 \\
\hline Cystathionine & 0.42 & 16.1 \\
\hline Isoleucine & 0.75 & 1.3 .3 \\
\hline Leucine & 2.18 & $4.5 \cdot 1$ \\
\hline Tyrosine & 1.39 & I 9.4 \\
\hline Phenylalanine & I. .4 & 19.8 \\
\hline Ornithine & 1.02 & 19.9 \\
\hline Eysine & I. 8.3 & $4 \mathrm{I} .2$ \\
\hline Tryptophan & & 3.1 \\
\hline Histicline & 0.85 & $\mathrm{I}+\mathrm{O}$ \\
\hline Arginine: & 0.97 & $(;, 6)$ \\
\hline
\end{tabular}

In Table II, the amino acids of serum and tumour tissue are given. Serum cystathionine was $0.42 \mathrm{mg}$ per $100 \mathrm{ml}$. No homocystine was found. Methionine, tyrosine and most other amino acids were normal, suggesting that hepatic amino acid metabolism was not grossly impaired. Glutamic acid and taurine were increased.

In the tumour the concentration of cystathionine ( $6.1 \mathrm{mg} / \mathrm{IOO} \mathrm{g}$ ) was higher than normal in liver, kidney and muscles ${ }^{8}$ but lower than ${ }^{8}$ or equal to $0^{9,10}$ that in brain. It is striking that all amino acid concentrations were high in this tumour tissue. The pattern is very different from that of adult liver and even of fetal liver published by Ryan and Carver ${ }^{11}$. It is, however, doubtful if any similarity is to be expected when the tissues are not obtained in the same way and treated identically. The presence of homocystine in the tumour could not conclusively be proved, although a small peak in the appropriate position is suggestive. The maximum possible concentration was $1.7 \mathrm{mg}$ per Ioo $g$. 
The excretion of common amino acids did not seem particularly abnormal. However, the sizes of some peaks in the column chromatogram (valine and aspartic acid) were not in agreement with the size of the spots on the paper chromatogram, whilst other peaks were asymmetric (Table I). We found that in the column chromatogram "valine" contained much homocitrulline. On the paper chromatogram the latter amino acid travels in the same position as $\beta$-aminoisobutyric acid. The last substance was absent in our patient's urine, in contrast with the results of Gjessing and Mauritzen ${ }^{1}$. According to Gerritsen et al. ${ }^{12}$, homocitrulline has its most likely origin in modified cow's milk preparations. The magnitude of the excretion in our patient was such, that this hypothesis is acceptable; there is no need to presume that homocitrulline is a tumour product.

Homocystine was not proved with certainty. If it was present at all, the quantity was small compared with cystathionine.

In the urine, no xanthurenic acid or kynurenine could be detected. This is not entirely conclusive for assuming that there is an adequate supply of vitamin $B_{6}$, for the patient was not charged with extra tryptophan. But a severe shortage of this vitamin did not seem probable.

\section{DISCLSSTON}

The observations of Gjessing ${ }^{13-15}$ on cystathioninuria in patients with neuroblastoma are in agreement with the concept that urinary cystathionine is produced by the primary tumour and also by its metastases. The magnitude of the excretion was thought to be proportional to the malignancy of the tumour. In a more recent publication, however, Gjessing' ${ }^{16}$ suggested that cystathioninuria in neuroblastoma was the result of disturbed liver function due to specific metastases in the liver. On the other hand, according to Shaw et al. ${ }^{2}$, urinary levels of cystathionine did not necessarily correlate with the presence of numerous metastases in neuroblastoma.

In our patient with hepatoblastoma there were no signs of gross liver dysfunction. In general, amino acid metabolism did not seem to be impaired. We did not find deviations of normal tryptophan metabolism suggesting a shortage of vitamin $B_{6}$. Statistically, congenital cystathioninuria in combination with hepatoblastoma must be very improbable. Therefore the acceptance of the origin of cystathionine in the tumour appears to be reasonable. However, a more direct proof by analysis of the blood draining from the tumour would be desirable.

At this moment, we only can speculate about the mechanism responsible for the release of the amino acid. Apparently there is little or no overflow of its precursor homocysteine, leading to abnormal homocystinuria. It seems possible that there is a shortage of cystathionase in the tumour cells and that these rells can only retain the accumulating cystathionine to a comparatively low concentration. Such an enzyme deficiency has still to be proved.

\section{REFERENCES}

I L. R. GJessing nnd K. Mauritzen, Scand. J. Clin. Lab. Inwest., I7 (1965) 513.

2 K. N. F. Shaw, E. Lieberman, R. Koch and G. N. Donnell, Am. J. Diseases Childyen, ir 3 , $(1967)$ irg. 
3 S. K. Wadman, F. J. van Sprang, G. J. van Stekelenburg and P. K. de Bree, Acta Paediat. Scand., $56(1967) 485$.

4 C. E. Dalgliesh, J. Clin. Pathol., 8 (1955) 73.

5 P. A. Vocte, Neuroblastoom, Ganglioneuroom on Phaeochromoctoom, Thesis, Utrecht, Ig68, Oosthoek, Utrecht, Ig68.

6 M. D. Armstrong, K. N. F. Shaw and A. McMildan, J. Biol. Chem., 2 I8 (1956) 293.

7 a G. J. van Stekelenburg, $12^{1 / 2}$-hour Chromatogram. 4 th Amino Acid Colloquium. Technicon, London, I966, p. 20.

7b G. J. van Stekelendurg and J. Desplangue, Deproteination by Ultra-filtration with Centrifugal Force. 4th Amino Acid Colloquium, Technicon, London, Ig66, p. 83.

8 H. H. Tallan, S. Moore and W. H. Stein, J. Biol. Chem., 230 (I958) 707.

9 H. Shimizu, Y. Kakimoto and 1. Sano, J. Neurochem., 13 (Ig66) 65.

ro L. R.Gjessing and A. Torvik, Scand. J. Clin. Lab. Invest., i 8 (1966) 565.

i I W. L. Ryan and M. J. Carver, Nature, 2 I 2 (I966) 292.

i2 T. Gerritsen, J. G. Vatghn and H. A. Waisman, Arch. Biochem. Biophys, roo (1963) 298.

I3 L. R. Gjessing, Scand. J. Clin. Lab. Imeest., I 5 (1963) 474.

I4 L. R. Gjessing, ibid., I $5\left(\operatorname{Ig}^{6} 3\right)+97$.

I 5 L. R. GJessing, Lancet, ii (1963) I28I.

I6 L. R. Gjessing, Advan. Clin. Chem., I ( 1968$)$ in the press.

Clin. Chim. Acta, 22(1968) $373-37^{8}$ 